\title{
Cryopreservation of Shoot Tips of Kiwifruit Seedlings by the Alginate Encapsulation-dehydration Technique
}

\author{
Mitsuteru Suzuki*, Takao NinNo** and Tomoya Akinama* \\ * Laboratory of Horticultural Plant Breeding, Faculty of Agriculture, Meiji University, \\ 1-1-1, Higashimita, Tama-ku, Kawasaki, Kanagawa 214, Japan \\ ** Tohoku National Agricultural Experiment Station, \\ 6000-1, Tohkamachi, Shinjo, Yamagata 996, Japan
}

(Received November 3, 1993)

(Accepted January 29, 1994)

Shoot tips from in vitro-grown seedlings of kiwifruit (Actinidia deliciosa (A. chev.) C. F. Liang et A. R. Ferguson var. deliciosa) were successfully cryopreserved by the encapsulation-dehydration technique.

Shoot tips cold-hardened at $5^{\circ} \mathrm{C}$ for 6 weeks were progressively precultured on agar media with increasing concentrations of sucrose $(0.1 \mathrm{M}, 0.4 \mathrm{M}$ and $0.7 \mathrm{M})$ daily at $5^{\circ} \mathrm{C}$. The cold-hardened and precultured shoot tips trapped into alginate-coated beads containing $0.5 \mathrm{M}$ sucrose were treated in a medium supplemented with 1.0 $\mathrm{M}$ sucrose for 16 hours at $5^{\circ} \mathrm{C}$. Beads containing one shoot tip were then dehydrated by up to $29 \%$ of their water content (fresh weight basis) on sterile dry silica gel in a desiccator at $25^{\circ} \mathrm{C}$. After dehydration, about 10 dried beads were placed in a $2-\mathrm{m} l$ cryotube and then immersed into liquid nitrogen $(\mathrm{LN})$. The average rate of shoot formation after rapid warming was about $80 \%$. This method will be useful for the long-term storage of kiwifruit germplasm.

\section{Introduction}

Cryopreservation of tissue-cultured plant cells, meristems and organs is an important method for long-term storage of plant genetic resources using a minimum of space and maintenance. Recently, vitrification ${ }^{1-3)}$, simple freezing ${ }^{4)}$ and air drying ${ }^{5,6)}$ methods have been presented to simplify the complicated procedures conventionally used for cryopreservation. Since alginate encapsulationdehydration technique was first reported by Dereuddre et $a l^{7)}$, there have been several reports of successful cryopreservation of alginate-coated shoot tips of pear $^{7)}$, grape ${ }^{8)}$, potato ${ }^{9)}$, mulberry ${ }^{10)}$, apple $^{11)}$ and sugarcane ${ }^{12)}$ after dehydration. The technique of alginate encapsulation is easy to handle and simplifies the dehydration treatment.

In this method, resistance to dehydration and deep freezing was induced by preculturing encapsulated shoot tips in a medium enriched with sucrose before dehydration. The sucrose molarity increased markedly during the drying process and reached or exceeded the saturation point of the sucrose solution, resulting in glass transition during cooling ${ }^{13,14}$. Sufficiently dehydrated samples easily vitrify during rapid cooling in LN. Vitrification refers to the physical process by which a highly concentrated cryoprotective solution supercools to very low temperatures and solidifies into metastable glass when undergoing crystallization ${ }^{15}$.

Kiwifruit (Actinidia deliciosa (A. chev.) C.F. Liang et A. R. Ferguson var. deliciosa) is a dioecious woody species of Actinidiaceae. It originated in China and was introduced into New Zealand at the beginning of the 20 th century. Kiwifruit is an important horticultural crop plant that is widespread 
around the world. There have been a few reports ${ }^{16-18)}$ on the storage of kiwifruit germplasm. In this study, we report a successful cryopreservation using the encapsulation-dehydration technique, and discuss the preculturing method to induce dehydration tolerance.

\section{Materials and Methods}

\section{Plant materials}

Seeds collected from fruits of kiwifruit plants (cultivar; Hayward, obtained from the field of YAMABUN-YUHOUEN, Higashiyamanashi, Yamanashi 405, Japan) were sterilized in 70\% (v/v) ethanol for $30 \mathrm{sec}$., and then in $0.5 \%(\mathrm{w} / \mathrm{v})$ sodium hypochlorite for $10 \mathrm{~min}$., followed by four rinses with sterilized water. The seeds were then placed on the Murashige and Skoog medium ${ }^{19)}(\mathrm{MS}$ medium) with half strength inorganic salts except for iron salts, containing $1.5 \%(\mathrm{w} / \mathrm{v})$ sucrose at pH 5.8 and solidified with $0.2 \%(\mathrm{w} / \mathrm{v})$ gellan gum in Petri dishes $(9 \mathrm{~cm}$ in diameter $)$, and germinated at $25^{\circ} \mathrm{C}$ under white fluorescent light $\left(40 \mu \mathrm{mol} \mathrm{m}^{-2} \mathrm{~s}^{-1}\right)$ during a $16-\mathrm{hr} /$ day photoperiod, for $40-50$ days.

\section{Pretreatment}

Seedlings of 2-3 leaves growth stages were cold-hardened at $5^{\circ} \mathrm{C}$ for 6 weeks under an 8 -hr/day photoperiod. Shoot tips of about $2 \mathrm{~mm}$ in length were excised from cold-hardened seedlings.

Preculture was performed at $5^{\circ} \mathrm{C}$ by successive daily transfer of the shoot tips onto MS media supplemented with sucrose at various concentrations $(0.1,0.4,0.7$ and $0.9 \mathrm{M})$ under an 8 -hr/day photoperiod.

\section{Alginate encapsulation}

Shoot tips were encapsulated in alginate beads as previously described ${ }^{11}$. Shoot tips were suspended in calcium chloride $\left(\mathrm{CaCl}_{2}\right)$-free MS liquid medium containing $3 \%(\mathrm{w} / \mathrm{v})$ sodium alginate and $0.5 \mathrm{M}$ sucrose at $\mathrm{pH}$ 5. 8. Alginate beads were obtained by dispensing the suspension into 50 $\mathrm{m} l$ of another MS liquid medium supplemented with $0.1 \mathrm{M} \mathrm{CaCl}_{2}, 0.5 \mathrm{M}$ sucrose and were held for $30 \mathrm{~min}$. at $25^{\circ} \mathrm{C}$. Beads of about $5 \mathrm{~mm}$ in diameter containing one shoot tip were treated in MS liquid medium supplemented with $1.0 \mathrm{M}$ sucrose at $\mathrm{pH} 5.8$ for 16 hours at $5^{\circ} \mathrm{C}$.

\section{Dehydration by desiccation with dry silica gel and cryopreservation}

After pretreatment, the surface solution was wiped off with sterilized filter paper and then the beads were subjected to dehydration in Petri dishes $(9 \mathrm{~cm}$ in diameter) containing $50 \mathrm{~g}$ silica gel sterilized by heating at $110^{\circ} \mathrm{C}$ for 16 hours. The Petri dishes were sealed with parafilm and held in a desiccator at $25^{\circ} \mathrm{C}$ for up to 25 hours. The final water content of the beads was about $25 \%$ on a fresh weight basis, when determined after drying for 48 hours at $110^{\circ} \mathrm{C}$. After dehydration, approximately 10 dried beads were placed in a $2-\mathrm{m} l$ plastic cryotube (Nalge Company) and then immersed into $\mathrm{LN}$ (cooling rate: $-375^{\circ} \mathrm{C} / \mathrm{min}$.), where they were stored for more than 1 hour.

\section{Determination of survival and plant regeneration}

Beads immersed in $\mathrm{LN}$ were warmed by placing the cryotubes in a water bath at $30^{\circ} \mathrm{C}$ (warming rate: $860^{\circ} \mathrm{C} / \mathrm{min}$.). Rewarmed beads were placed on ammonium nitrate $\left(\mathrm{NH}_{4} \mathrm{NO}_{3}\right)$-free $\mathrm{MS}$ medium containing $3.0 \%(\mathrm{w} / \mathrm{v})$ sucrose and $1 \mathrm{mg} / \mathrm{l}$-benzyladenine (BA), and solidified with $0.8 \%$ $(\mathrm{w} / \mathrm{v})$ agar at $\mathrm{pH} 5.8$, and recultured under a $16-\mathrm{hr} /$ day photoperiod at $25^{\circ} \mathrm{C}$. The rate of shoot formation was defined as the percentages of shoot tips that produced normal shoots about 40 days after plating.

Normal shoots were transferred to a rooting medium of the $\mathrm{N} 6$ medium ${ }^{20)}$ with half strength of inorganic salts containing $1.5 \%(\mathrm{w} / \mathrm{v})$ sucrose solidified with $1.0 \%(\mathrm{w} / \mathrm{v})$ agar at $\mathrm{pH} 5.8$. 


\section{Results}

Cold-hardening before preculture was significant for shoot tips to survive after exposure to LN (data not shown). Progressive preculture by transfer daily to MS media containing $0.1,0.4$ and $0.7 \mathrm{M}$ sucrose led to a high level of shoot formation amounting to about $85 \%$ after exposure to $\mathrm{LN}$ (Table 1). The treatment with 1. $0 \mathrm{M}$ sucrose before dehydration also improved the survival of cryopreserved shoot tips.

The time course of dehydration of alginate beads containing one shoot tip is shown in Fig. 1. The water content of the original alginate beads including one shoot tip decreased rapidly from $70 \%$ to $35 \%$ within 4 hours, and then decreased slowly down to $25 \%$.

Shoot formation of cold-hardened and precultured alginate-coated shoot tips before and after exposure to LN following dehydration is shown in Fig. 2. The rate of shoot formation of alginate

Table 1. Effect of preculturing conditions on shoot formation of alginate-coated shoot tips exposed to $\mathrm{LN}$ after dehydration.

\begin{tabular}{|c|c|}
\hline $\begin{array}{l}\text { Preculturing condition } \\
\text { (sucrose concentration }(\mathrm{M}) \text { and duration) }\end{array}$ & $\begin{array}{l}\text { Shoot formation } \\
\quad(\% \pm \mathrm{SE})\end{array}$ \\
\hline \multicolumn{2}{|l|}{ With treatment of $M S$ medium containing $1 . O M$ sucrose } \\
\hline $0.1 \mathrm{M}$ (1 day) $\rightarrow 0.4 \mathrm{M}$ (1 day) & $41.8 \pm 1.5$ \\
\hline $0.1 \mathrm{M}(1$ day $) \rightarrow 0.4 \mathrm{M}(2$ & \\
\hline $0.1 \mathrm{M}(1$ day $) \rightarrow 0.4 \mathrm{M}$ (1 day) $\rightarrow 0.7 \mathrm{M}$ (1 day) & 5.3 \\
\hline $0.1 \mathrm{M}(1$ day $) \rightarrow 0.4 \mathrm{M}(1$ day $) \rightarrow 0.7 \mathrm{M}(2$ days $)$ & 16. \\
\hline $0.1 \mathrm{M}(1$ day $) \rightarrow 0.4 \mathrm{M}(1$ day $) \rightarrow 0.7 \mathrm{M}(1$ day $) \rightarrow 0.9 \mathrm{M}(1$ day $)$ & $16.7 \pm 9.8$ \\
\hline Without treatment of MS medium containing 1. O M sucrose & \\
\hline $0.1 \mathrm{M}(1$ day $) \rightarrow 0.4 \mathrm{M}$ (1 day) $\rightarrow 0.7 \mathrm{M}$ (1 day) & $74.4 \pm 1.4$ \\
\hline \multicolumn{2}{|c|}{$\begin{array}{l}\text { Cold-hardened and precultured shoot tips were encapsulated in alginate gel beads including } 0.5 \\
\mathrm{M} \text { sucrose and then treated in MS liquid medium containing } 1.0 \mathrm{M} \text { sucrose at } 5^{\circ} \mathrm{C} \text { for } 16 \text { hours } \\
\text { before dehydration. These beads were subjected to dehydration for about } 9 \text { hours at } 25^{\circ} \mathrm{C} \text {. } \\
\text { Dehydrated shoot tips placed in a cryotube were immersed into } \mathrm{LN} \text {. After rapid warming, they } \\
\text { were transferred onto agar } \mathrm{NH}_{4} \mathrm{NO}_{3} \text {-free MS medium containing } 3.0 \%(\mathrm{w} / \mathrm{v}) \text { sucrose and } 1 \\
\mathrm{mg} / l \mathrm{BA} \text { after exposure to } \mathrm{LN} \text {. Approximately } 10 \text { shoot tips were treated for each of } 3 \\
\text { replicates. }\end{array}$} \\
\hline
\end{tabular}

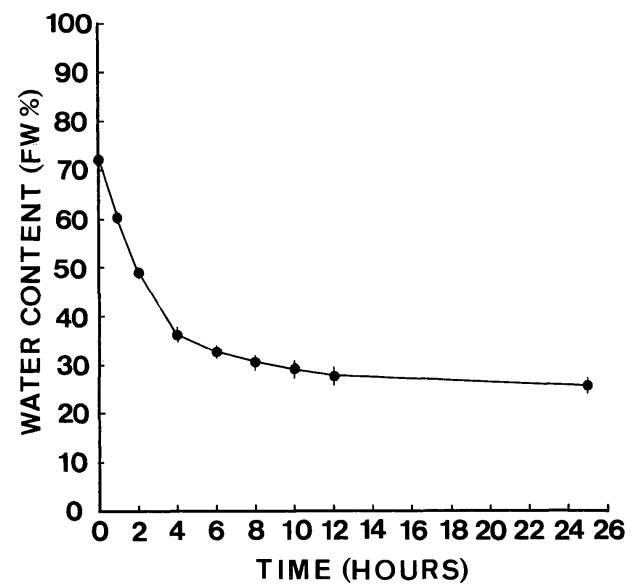

Fig. 1 The time course of water content of alginate beads containing one shoot tip. Alginate beads were placed on a parafilm-sealed Petri dish $(9 \mathrm{~cm}$ in diameter) containing $50 \mathrm{~g}$ silica gel were placed in a desiccator at $25^{\circ} \mathrm{C}$ for varying length of time. Approximately 7 beads were tested for each of 3 replicates. 


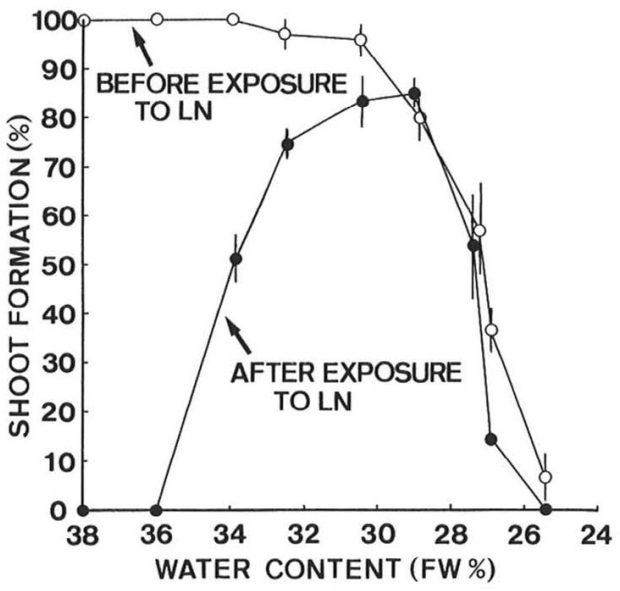

Fig. 2 Shoot formation of dehydrated alginate-coated shoot tips before and after exposure to LN.

Cold-hardened, precultured shoot tips were trapped into alginate beads containing 0.5 $\mathrm{M}$ sucrose and then treated in MS medium supplemented with $1.0 \mathrm{M}$ sucrose for 16 hours at $5^{\circ} \mathrm{C}$. Beads containing one shoot tip were dehydrated at varying water content. Dehydrated shoot tips placed in a plastic cryotube were immersed into LN. After rapid warming, the beads were transferred onto agar $\mathrm{NH}_{4} \mathrm{NO}_{3}$-free MS medium containing $3.0 \%(\mathrm{w} / \mathrm{v})$ sucrose and $1 \mathrm{mg} / l \mathrm{BA}$.

Cold-hardening was carried out at $5^{\circ} \mathrm{C}$ for 6 weeks with an 8 -hr/day photoperiod. Preculture was carried out at $5^{\circ} \mathrm{C}$ by successive daily transfer of the shoot tips onto agar media supplemented with increasing sucrose (0.1,0.4 and $0.7 \mathrm{M})$. Approximately 10 shoot tips were treated for each of 3 replicates.

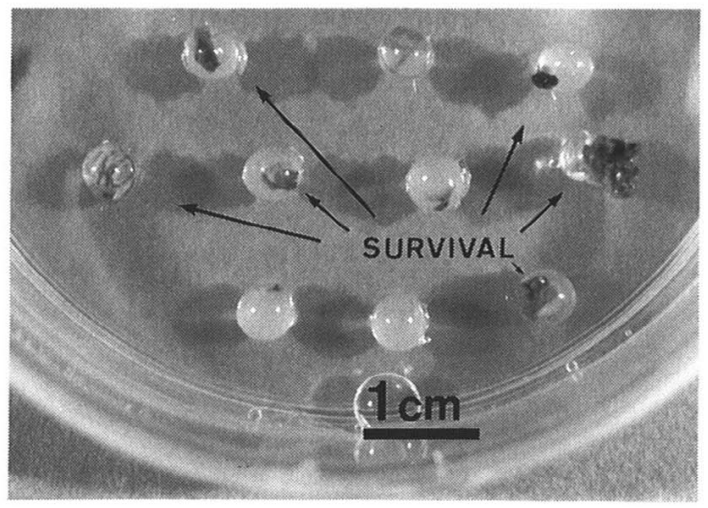

Fig. 3 Survival of cryopreserved shoot tips of kiwifruit seedlings encapsulated in alginate beads at 14 days after reculturing.

beads including one shoot tip after dehydration without cooling to $-196^{\circ} \mathrm{C}$ was approximately $100 \%$ at $34-72 \%$ water content, and then gradually decreased with decreasing water content.

Shoot formation of cold-hardened and precultured alginate-coated shoot tips cooled to $-196^{\circ} \mathrm{C}$ following dehydration increased abruptly with decreasing water content from 36 to $30 \%$, and reached the highest rate of approximately $85 \%$ at about $29 \%$ water content (duration of dehydration: about 9 hours). Subsequently, the rate of shoot formation significantly decreased with decreasing water content due to desiccation injury.

The cryopreserved shoot tips resumed growth in about 3 days after placing on the culture medium. So the growing rate of cryopreserved shoot tips at 30 days after reculturing was about 3 


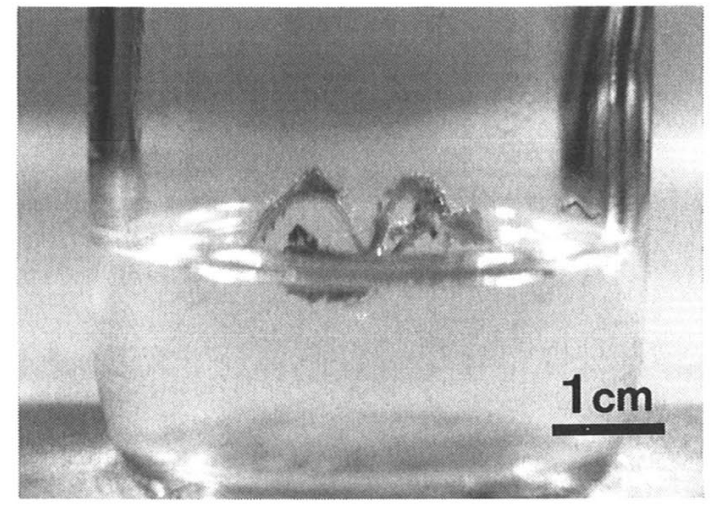

Fig. 4 Shoot formation of cryopreserved shoot tip at 30 days after reculturing.

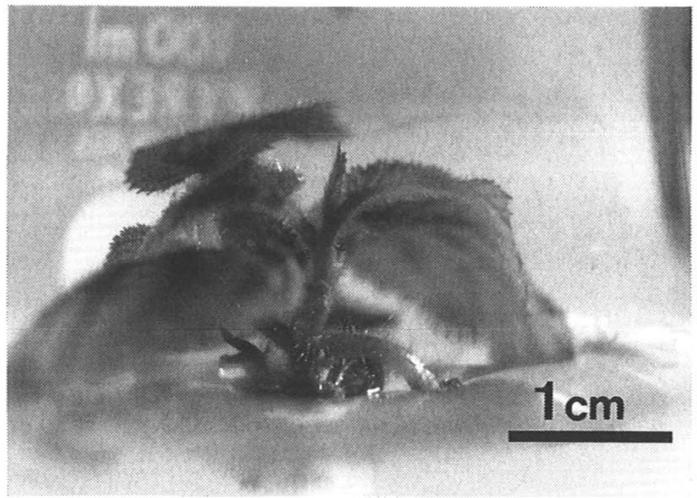

Fig. 5 Plantlet development of cryopreserved shoot tip at 60 days after reculturing.

-4 days later than that of the non-cryopreserved controls.

Figs. 3, 4 and 5 show alginate-coated shoot tips and shoots developed from the shoot tips cooled to $-196^{\circ} \mathrm{C}$ following dehydration. Almost all of the shoots formed roots after transfer to the root induction medium.

\section{Discussion}

The development of techniques to successfully store apical meristems in LN is needed for conservation of genetic resources of fruit trees. In vitro-grown shoots are a preferable source for germplasm preservation. For successful cryopreservation, it is vital to dehydrate sufficiently cells or meristems to make them survive upon rapid cooling into $\mathrm{LN}$ through vitrification ${ }^{21)}$. The conventional slow freezing method prevents cells and meristems from lethal intracellular freezing and allows them to undergo vitrification upon rapid cooling in LN. Another simple cryogenic protocol is to highly dehydrate meristems by air drying ${ }^{5,22)}$. However, the induction or enhancement of desiccation tolerance is vital for successful cryopreservation using this method. Dried axillary buds from in vitro-grown asparagus were successfully cryopreserved by Uragami et al. ${ }^{5)}$. In their experiment, single nodal segments with axillary buds were precultured on solidified culture medium containing $0.7 \mathrm{M}$ sucrose at $25^{\circ} \mathrm{C}$ for 2 days. During the pretreatment, water content decreased to about $16.4 \%$ and dry matter (mainly sugar) increased approximately 2.7 times. Alfalfa somatic embryos at the cotyledonary stage of development were treated with abscisic acid $(\mathrm{ABA})$ to induce desiccation tolerancel ${ }^{23)}$. Anandarajah and McKersie ${ }^{24)}$ reported that high sucrose concentrations in the maturation medium of somatic embryos of alfalfa can be substituted for 
exogenous ABA-induced desiccation tolerance of somatic embryos. A high level of sugar ${ }^{14,25,26)}$ or sorbitol ${ }^{23)}$ during preculture was reported to be important in improving survival of cryopreserved meristems. In the present study, progressive preculture in media with increasing sucrose concentrations enhanced dehydration tolerance of kiwifruit meristems.

Recently it was reported that induction and maintenance of freezing tolerance by $A B A$ is accompanied by the expression of novel polypeptides and translatable RNAs, and that expression of genes related to sugar metabolism may be required for ABA-induced hardening ${ }^{25)}$. Dormant seeds and young seedlings of wheat tolerate desiccation. A transcript expressed in this desiccationtolerant tissue has been cloned and sequenced ${ }^{27)}$. The proteins abundant late in embryogenesis accumulate at a late stage of embryogenesis of desiccation-tolerant seeds or seedlings and often in the cold acclimation process ${ }^{26,27)}$. These proteins are highly hydrophilic, and may help maintain a minimal water content during dehydration ${ }^{25-27)}$.

Alginate protects shoot tips from injury during dehydration and freeze-thaw treatments and alleviates excessively rapid dehydration of the samples. Shoot tips trapped in alginate gel beads were progressively dehydrated osmotically with increasing concentration of sucrose in the beads. Thus, the slow dehydration process may allow the shoot tips and somatic embryos to resist intensive dehydration. During dehydration of the shoot tips trapped in alginate beads, sucrose molarity increases significantly and the resulting concentrated cell sap may undergo a glass transition during rapid cooling ${ }^{14)}$. Thus, drying method using alginate-coated shoot tips is easy to handle and alleviates the dehydration process ${ }^{7,10,11,28)}$. Our results presented here show that the encapsulation -dehydration technique is promising as a practical method for cryopreservation of plant meristems.

As far as we know, this is the first report of successful cryopreservation of kiwifruit meristems by the drying method.

\section{Acknowledgments}

The authors wish to thank to Dr. A. Sakai, professor emeritus of Hokkaido University for reviewing the manuscript, Mr. K. Nozawa, YAMABUN-YUHOUEN for supplying 'Hayward' of kiwifruit cultivar and TAISEI CORPORATION for supporting in this work.

\section{References}

1) Uragami, A., A. Sakai, M. Nagai, T. Takahashi, 1989. Plant Cell Rep., 8: 418-421.

2) Sakai, A., S. Kobayashi, I. Oiyama, 1990. Plant Cell Rep., 9: 30-33.

3) Yamada, T., A. Sakai, T. Matsumura, S. Higuchi, 1991. Plant Sci., 78: 81-87.

4) Niino, T., H. Yakuwa, K. Sato, A. Sakai, 1991. Plant Tissue Culture Letters, 8: 185-189 (in Japanese with English summary).

5) Uragami, A., A. Sakai, M. Nagai, 1990. Plant Cell Rep., 9: 328-331.

6) Shimonishi, K., M. Ishikawa, S. Suzuki, K. Oosawa, 1991. Japan. J. Breed., 41: 347-351.

7) Dereuddre, J., C. Scottez, Y. Arnaud, M. Duron, 1990. C. R. Acad. Sci., Paris, sér. III., 310: 317-323.

8) Plessis, P., C. Leddet, J. Dereuddre, 1991. C. R. Acad. Sci., Paris, sér. III., 313: 373-381.

9) Fable, J., J. Dereuddre, 1990. Cryo-Letters, 11: 413-426.

10) Niino, T., A. Sakai, H. Yakuwa, 1992. Cryo-Letters, 13: 51-58.

11) Niino, T., A. Sakai, 1992. Plant Sci., 87: 199-206.

12) Paulet, F., F. Engelmann, J. C. Glaszmann, 1993. Plant Cell Rep., 12: 525-529.

13) Dereuddre, J., S. Blandin, N. Hassen, 1991. Cryo-Letters, 12: 125-134.

14) Dereuddre, J., N. Hassen, S. Blandin, M. Kaminski, 1991. Cryo-Letters, 12: 135-148.

15) Fahy, G. M., D. R. MacFarlane, C. A. Angell, H. T. Meryman, 1984. Cryobiology, 21: 407-426. 
16) Monette, P. L., 1986. Hort Sci., 21: 1203-1205.

17) Monette, P. L., 1987. Scientia Hortic., 31: 101-106.

18) Jian, L.-C., L.-H. Sun, 1989. Acta Botanica Sinica, 31: 66-68 (in Chinese).

19) Murashige, T., F. Skoog, 1962. Physiol. Plant., 15: 473-497.

20) Chu, C. C., C. C. Wang, C. S. Sun, C. Hsu, K. C. Yin, C. Y. Chu, F. Y. Bi, 1975. Sci. Sinica., 18: 659-668.

21) Sakai, A., 1993. In "Cryopreservation of Plant Genetic Resources" (ed. by Sakai, A.), Genetic Resources Projects, REF No. 6, p. 5-26, JICA, Tokyo.

22) Nitzsche, W., 1980. Z. Pflanzenphysiol., 100: 269-271.

23) Senaratna, T., B. D. McKersie, S. R. Bowley, 1990. In Vitro Cell Dev. Biol., 26: 85-90.

24) Anandarajah, K., B. D. McKersie, 1990. Plant Cell Rep., 9: 451-455.

25) Lee, S. P., T. H. H. Chen, 1993. Plant Physiol., 101: 1089-1096.

26) Guo, W., R. W. Ward, M. F. Thomashow, 1992. Plant Physiol., 100: 915-922.

27) Ried. J. L., M. K. Walker-Simmons, 1993. Plant Physiol., 102: 125-131.

28) Uragami, A., M. O. Lucas, J. Ralambosoa, M. Renard, J. Dereuddre, 1993. Cryo-Letters, 14: 83-90.

\title{
《和文要約》
}

アルギン酸ビーズ乾燥法を用いたキウイフルーツ実生の茎端の超低温保存

\author{
鈴木光輝 $*$ 新野孝男 $* * \cdot$ 秋濱友也* \\ *明治大学農学部園芸育種学研究室 \\ $* *$ 農林水産省東北農業試験場 作物開発部遺伝資源利用研究室
}

\begin{abstract}
アルギン酸ビーズ乾燥法を用いて，キウイフルーツ実生の茎端が凍結保存できるかを検討した，その結果，

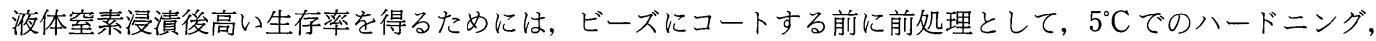
高濃度のショ糖による前培養が不可欠であった。最も高いシュート再生率(約 $85 \%$ ) が得られたのは，以下 の方法であった、ハードニング, 前培養した約 $2 \mathrm{~mm}$ の茎端を $0.5 \mathrm{M}$ ショ糖を含むアルギン酸カルシウム でコートし，茎端を 1 つ含む直径約 $5 \mathrm{~mm}$ のビーズを作成する。そのビーズを $1 \mathrm{M}$ ショ糖を含む培地で $5^{\circ} \mathrm{C}$ ・約 16 時間処理後, 含水率が約 $29 \%$ になるまで乾燥し, 液体窒素に浸漬する. 再生は急速融解後, ビ 一ズのまま培養する。この方法は，キウイフルーツの遺伝資源をインビトロで超低温保存する一方法になり
\end{abstract} 得るものと考えられた。 